\title{
Heterozygous Trees Rebound the Fastest after Felling by Beavers to Positively Affect Arthropod Community Diversity
}

\author{
Faith M. Walker ${ }^{1,2}$, Rachel Durben ${ }^{1}$, Stephen M. Shuster ${ }^{1}\left(\mathbb{D}\right.$, Richard L. Lindroth ${ }^{3} \mathbb{C}$ and Thomas G. Whitham ${ }^{1, *}$ \\ 1 The Environmental Genetics and Genomics Laboratory and the Center for Adaptable Western Landscapes, \\ Department of Biological Sciences, Northern Arizona University, Flagstaff, AZ 86011, USA; \\ Faith.Walker@nau.edu (F.M.W.); rdurben@gmail.com (R.D.); Stephen.Shuster@nau.edu (S.M.S.) \\ 2 School of Forestry, Northern Arizona University, Flagstaff, AZ 86001, USA \\ 3 Department of Entomology, University of Wisconsin-Madison, Madison, WI 53706, USA; \\ richard.lindroth@wisc.edu \\ * Correspondence: Thomas.Whitham@nau.edu
}

\section{check for} updates

Citation: Walker, F.M.; Durben, R.; Shuster, S.M.; Lindroth, R.L.; Whitham, T.G. Heterozygous Trees Rebound the Fastest after Felling by Beavers to Positively Affect Arthropod Community Diversity. Forests 2021, 12, 694. https: / / doi.org/10.3390/f12060694

\section{Academic Editors:}

Julianne O'Reilly-Wapstra and Ben Moore

Received: 20 March 2021

Accepted: 27 May 2021

Published: 28 May 2021

Publisher's Note: MDPI stays neutral with regard to jurisdictional claims in published maps and institutional affiliations.

Copyright: (c) 2021 by the authors. Licensee MDPI, Basel, Switzerland. This article is an open access article distributed under the terms and conditions of the Creative Commons Attribution (CC BY) license (https:// creativecommons.org/licenses/by/ $4.0 /)$.

\begin{abstract}
Although genetic diversity within stands of trees is known to have community-level consequences, whether such effects are present at an even finer genetic scale is unknown. We examined the hypothesis that genetic variability (heterozygosity) within an individual plant would affect its dependent community, which adds a new dimension to the importance of genetic diversity. Our study contrasted foliar arthropod community diversity and microsatellite marker-derived measures of genetic diversity of cottonwood (Populus fremontii) trees that had been felled by beavers (Castor canadensis) and were resprouting, relative to adjacent standing, unfelled trees. Three patterns emerged: 1. Productivity (specific leaf area), phytochemical defenses (salicortin), and arthropod community richness, abundance, and diversity were positively correlated with the heterozygosity of individual felled trees, but not with that of unfelled trees; 2 . These relationships were not explained by population substructure, genetic relatedness of the trees, or hybridization; 3 . The underlying mechanism appears to be that beaver herbivory stimulates increased productivity (i.e., $2 \times$ increase from the most homozygous to the most heterozygous tree) that is the greatest in more heterozygous trees. Salicortin defenses in twigs were also expressed at higher concentrations in more heterozygous trees (i.e., $3 \times$ increase from the most homozygous to the most heterozygous tree), which suggests that this compound may dissuade further herbivory by beavers, as has been found for other mammalian herbivores. We suggest that high stress to trees as a consequence of felling reveals a heterozygosityproductivity linkage, which in turn is attractive to arthropods. Although experiments are required to demonstrate causality, these results link the genetic diversity of individual trees to community diversity, supporting the hypothesis that interactions among foundation species (beavers and trees) have community-level effects, and underscores the importance of genetic diversity for biodiversity, conservation, and restoration.
\end{abstract}

Keywords: individual multilocus heterozygosity; beaver herbivory; arthropod diversity; Populus fremontii

\section{Introduction}

A growing number of reviews show that dominant or foundation species can have extended genetic effects that impact associated communities, ecosystem processes, and evolution [1-8]. These effects are a consequence of genetic variability, which is organized hierarchically. The broadest levels of genetic effects involve a number of unique individuals (genotypes) within a population, which can consist of genotypes within species or, more loosely, hybrid genotypes of closely related sympatric species. Such genetic variation is most accurately referred to as genotypic diversity [9]. Molecularly assessed genetic diversity, also usually a within-population metric, is measured as allelic diversity (the number of unique alleles in a sampled population) and as mean heterozygosity (the average 
heterozygosity in a population). The finest level of genetic diversity is measured within the genotype itself as individual heterozygosity (the proportion of heterozygous loci sampled in an individual).

At present, the within-population levels of genotypic and genetic diversity have been evaluated among pure parental species and their hybrids [10,11] and among genotypes within an individual species [4,9]. In both cases, greater genetic variation among plants within a plot or stand is associated with greater biodiversity in associated communities that range from soil microbes to arthropods [2,10,12-15]. Intraspecific variation in the communities of individual plant genotypes is also associated with heritable differences in community stability, resistance to environmental change, and community network structure $[9,16]$. These results are largely driven by differences in plant traits that make each plant unique in functional traits (i.e., the multivariate phenotype; [17]), which in turn results in different genotypes supporting different communities of organisms and ecosystem processes such as decomposition and nutrient cycling $[5,18]$.

Elegant examples in trees come from species such as cottonwoods (Populus spp.) and eucalypts (Eucalyptus globulus), for which associated arthropod community diversity was dictated by tree genotypic diversity $[11,19,20]$. In common garden experiments, Evans et al. [15] found that growth rate was a heritable trait and that faster growing genotypes of $P$. angustifolia supported greater arthropod species richness, abundance, and Shannon diversity $H^{\prime}$ than slower growing genotypes. Similarly, Barker et al. [21] demonstrated that $P$. tremuloides size, phenology, and foliar chemistry influenced arthropod abundance and diversity. These studies reveal that tree productivity is positively correlated with community diversity metrics, which was observed at individual tree, genotype mean, and population mean levels. The similarity of results in evolutionarily disparate tree species suggests that the genetic diversity-begets biodiversity relationship may commonly occur. However, although this effect has been demonstrated at two different levels, the even finer level of genetic diversity remains to be fully explored, i.e., the genetic variation within an individual plant that can be quantified as heterozygosity. Bringing community effects of genetic diversity down to their root level—that of the foundation individual—would demonstrate the fundamental importance of genetic diversity to biodiversity, and reinforce the relevance of the individual to ecology and restoration.

Individual multilocus heterozygosity (IMH) at microsatellite or SNP loci has received considerable attention due to heterozygosity-fitness correlations, which have been discussed for over 40 years [22]. Heterozygosity-fitness correlations are broadly distributed across taxa in natural populations $[23,24]$, but the signal is usually weak and is contextspecific $[23,25]$. Strong correlations can occur, but only when particular population structures or histories promote them, and as such, they are a characteristic of populations and not of species per se. For heterozygosity-fitness correlations to arise, there must be a proportion of consanguineous matings [26], population bottlenecks or genetic drift in small populations [27], or admixture or immigration [28]. These processes generate variation in inbreeding and a correlation in heterozygosity across loci (identity disequilibrium). Hence, heterozygosity-fitness correlations are not expected in large panmictic populations at equilibrium. Instead, they are primarily present when inbreeding, as a result of population characteristics, is pronounced and when it explains the variance in fitness [22]. Inbreeding depression, the reduction of performance in fitness-related traits [29], likely generates this variation in inbreeding levels and the relationship between heterozygosity and fitness. It is caused by the expression of deleterious recessive or partially recessive alleles due to mating between relatives in small populations or self-pollination in a mixed mating system. Heterozygosity-fitness correlations are only expected when many loci controlling a trait have directional dominance, such as for growth or life-history traits. A heterozygote excess is present when alleles of a neutral molecular marker locus are in linkage disequilibrium with different partially recessive deleterious variants that are masked by dominant alleles on the homologous chromosome (associative overdominance; [27]). Homozygotes, on 
the other hand, have lowered fitness because they are homozygous for the associated detrimental variants.

The popularity of examining heterozygosity-fitness correlations stems from the ease of acquiring genetic data (microsatellites, SNPs, allozymes), dovetailed with a growing capacity of long-term studies to investigate selection in the wild [23]. These correlations have overwhelmingly been investigated in vertebrates, and while many have found no relationship, others have found heterozygosity-fitness correlations for morphological (size, shape [30]), physiological (parasite resistance [31-33]), and life-history traits (survival, reproductive success, dispersal, phenotypic performance [34-37]). In plants, heterozygosity-fitness correlations have been found for fitness traits such as flowering shoots or twigs [38,39], clone size [40], and growth [39,41-43].

In the present study, we focused on a small, semi-arid riparian system that is likely to have the population structure and/or history necessary for heterozygosity-fitness correlations. We targeted trees that had been felled by beavers (Castor canadensis) and were resprouting from their stumps (Figure 1). Beaver felling represents a stressful event for these trees, as felled trees lose nearly all of their aboveground biomass and may die. However, many resprout from the stump using reserves stored in the roots, essentially converting a mature tree to a juvenile state. We sought a trait that is both indicative of tree productivity and would affect a diverse arthropod community. A few key attributes of leaf quality appear to predictably drive generalist herbivore preferences, regardless of the complexities of plant-herbivore interactions [44]. We examined one of these, i.e., specific leaf area (SLA), which is consistently positively correlated with relative growth rate in young trees $[39,45,46]$. We also examined the phytochemistry of resprout growth, since defensive chemistry has been found to deter browsing mammals [47-49], and the degree of inbreeding has been found to be negatively correlated with defensive chemistry [50-52].

With these data, we hypothesized that (1) individual Fremont cottonwood trees harboring greater genetic diversity (IMH) would affect the diversity of their dependent arthropod communities. Because individual multilocus heterozygosity is an individual tree metric and not a population metric, herein we often refer to IMH in the singular (i.e., a tree's IMH). If substantiated, this IMH/arthropod diversity relationship would likely result from other more proximal factors that affect arthropods such as productivity. To explore this potential mechanism, we hypothesized that (2) greater genetic diversity (IMH) would be associated with greater productivity (i.e., the heterozygosity-productivity hypothesis), which has been shown to be attractive to arthropods [15]. We also hypothesized that (3) the IMH/arthropod relationship would not be present in the juvenile growth of trees not felled by beavers because they would not have been stimulated by herbivory. Additionally, we hypothesized that (4) greater genetic diversity (IMH) would be associated with phytochemical defenses (i.e., the phenolic glycoside salicortin; the heterozygosity-phytochemistry hypothesis), as beaver felling of trees could induce phytochemical changes in resprout twigs that may act to deter further browsing by beavers. Answers to these hypotheses are important because our observations appear to reveal changes in tree and community phenotypes resulting from biotic stress caused by beaver herbivory. In a time of great environmental change in the American Southwest, where an ongoing 19-year-long drought is considered to be the second worst in 1200 years [53], multiple stressors are likely to affect plant survival and the communities they support. Our research enhances the understanding of (a) how biotic stressors such as beavers interact with genetics to affect plant performance and (b) whether genetic diversity at the individual tree level has the potential to impact associated communities. Recent studies have shown that selection acting on the tree is also acting on its associated community of herbivores and can lead to community evolution [5]; therefore, it is important to consider the cascading effects of interactions at higher levels. 

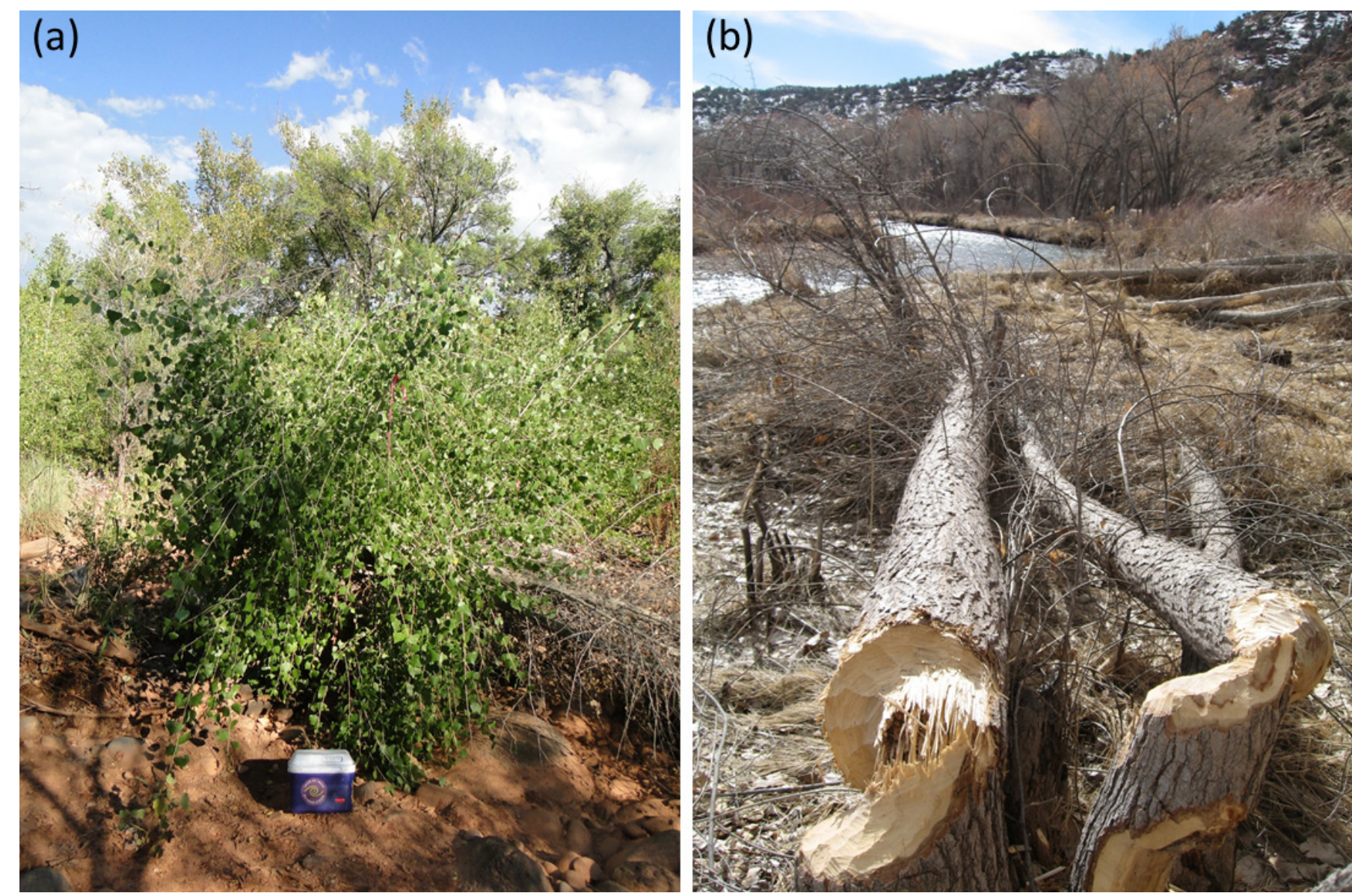

Figure 1. A Fremont cottonwood tree that was felled by beaver and subsequently resprouted (a) and cottonwood trees that were felled by beaver during the winter, that may or may not resprout in the spring (b). For scale, the cooler in (a) was $25 \mathrm{~cm}$ wide, and the trees in (b) were $25-30 \mathrm{~cm}$ in diameter.

\section{Materials and Methods}

\subsection{Study Site}

This study took place on Arizona's Verde River, a perennial stream, and on two of its intermittently flowing tributaries, Dry Beaver Creek and Red Tank Draw. The maximum straight-line distance between sites was $21.1 \mathrm{~km}$. P. fremontii is a dominant tree and the preferred food of beavers in this riparian system [54] and others [55]. Fifty trees were selected for the study (Verde, $\mathrm{N}=14$; Dry Beaver Creek, $\mathrm{N}=26$; Red Tank Draw, $\mathrm{N}=10$ ). Half of the selected trees at each site had been felled by beavers and were resprouting from their stumps, and the other half were unfelled. These were a set of the study trees of Durben et al. [54], who randomly selected a tree that had been felled by beaver and had resprouted from its base and then selected the nearest tree of the same size and at the same distance from the river that had not been felled by beaver to serve as a control. This pairing allowed standardization for resource availability (i.e., distance from the river, within $30 \mathrm{~m}$ ) and tree size, as beavers can be sensitive to both of these variables. All necessary permits were obtained for the described study, which complied with all relevant USA regulations.

\subsection{Arthropod Surveys and Twig Chemistry}

In August 2009, we performed non-destructive visual arthropod surveys. Because juvenile and mature foliage can support different arthropod communities [56], to standardize for plant ontogeny, only the juvenile foliage at the base of unfelled trees was used to contrast with the juvenile foliage of resprouting beaver-felled trees. We sampled the same amount of foliage on resprouting beaver-felled trees and unfelled trees by following the methods of Wimp et al. [57,58], by which we measured each branch until we reached a total 
of $20 \mathrm{~mm}$ of branch diameter to standardize for less growth on resprout trees compared to unfelled trees. Thus, both groups of trees represented random samples, and our standardizations across groups allowed them to be compared relative to their phytochemistry, genetics, and arthropod communities. We observed each set of branches for $20 \mathrm{~min}$ and identified arthropods as species or morphospecies within a family or genus. Unknown arthropods were identified via a reference collection at the Colorado Plateau Biodiversity Center at Northern Arizona University. We found 24 species in six orders (Lepidoptera, Hemiptera, Thysanoptera, Coleoptera, Hymenoptera, and Araneae).

We analyzed phytochemistry from twigs instead of leaves because beavers forage on the cambium layer of trees. We wished to assess whether beaver felling of trees might induce chemical defenses against further herbivory and other chemical changes of resprout growth (reported in Durben et al. [54]) and whether these might be associated with tree heterozygosity. We chose phytochemical traits that were previously found important: salicortin and total nitrogen (Martinsen et al. [59]). We quantified salicortin and nitrogen in $45 \mathrm{~cm}$ of terminal plant growth of the juvenile region of each tree according to the methods of Lindroth et al. [60]. We used dry ice to flash-freeze twigs in the field. Twigs were ground in a Wiley mill to pass through a 40-mesh screen. We employed high-performance thinlayer chromatography (HPTLC) to quantify salicortin [60]. We used a Thermo Finnigan Flash 1112 elemental analyzer (Thermo Finnigan, San Jose, CA, USA) to assess nitrogen [61]. Results are reported as \% dry weight; additional methods are provided by Durben et al. [54].

\subsection{Microsatellite Genotyping}

We collected fresh leaves from each tree and immediately placed them in Ziploc bags containing calcium sulfate (Drierite; [62]). After desiccation, seven $\sim 0.6 \mathrm{~cm}$ discs of tissue were removed from a leaf from each tree using a standard paper punch, total genomic DNA was extracted after leaf homogenization using the DNeasy plant miniprep kit (QIAGEN, Valencia, CA, USA), and DNA concentrations were estimated using a NanoDrop fluorometer (Thermo Fisher Scientific Inc., Waltham, MA, USA).

We employed a suite of 9 hypervariable (mean expected heterozygosity $\left[\mathrm{H}_{\mathrm{E}}\right]=0.61$ ) microsatellite loci (GCPM333, 831, 961, 1176, 2425, 2885, 3457, 3592, and 3907) procured from the Populus trichocarpa whole-genome sequencing project [63]. Populus has 19 linkage groups [64]; to maximize the independence of loci, ours were located on 8 of them. We amplified DNA using polymerase chain reaction (PCR) carried out in total volumes of 10 and $20 \mu \mathrm{L}$ on Bio-Rad DNA Engine Tetrad 2 and iCycler thermal cyclers (Bio-Rad Laboratories, Hercules, CA, USA), respectively. PCR reactions contained $1 \times \mathrm{Mg}$-free buffer (Bio-Rad), $1.5 \mathrm{mM} \mathrm{MgCl}$ (Bio-Rad), $0.2 \mathrm{mg} / \mathrm{mL}$ bovine serum albumin (Ambion, Austin, TX, USA), $0.2 \mathrm{mM}$ of each dNTP, $0.2 \mu \mathrm{M}$ fluorescent dye-labeled (VIC, FAM, NED, PET) forward and unlabeled reverse primers (Integrated DNA Technologies, Inc., Coralville, IA, USA), $0.05 \mathrm{U} / \mu \mathrm{L}$ iTaq DNA polymerase (Bio-Rad), and $25 \mathrm{ng}$ DNA template. Cycling involved an initial step of $95^{\circ} \mathrm{C}$ for $5 \mathrm{~min}$, then 9 cycles of a touchdown PCR $\left(15 \mathrm{~s}\right.$ at $95^{\circ} \mathrm{C}$, $15 \mathrm{~s}$ at annealing $\left[58^{\circ} \mathrm{C}\right.$, decreasing by $1^{\circ} \mathrm{C}$ each cycle], $30 \mathrm{~s}$ at $72{ }^{\circ} \mathrm{C}$ ), followed by 20 cycles as above but with an annealing temperature of $50{ }^{\circ} \mathrm{C}$ for $15 \mathrm{~s}$ and a concluding step of $72{ }^{\circ} \mathrm{C}$ for $3 \mathrm{~min}$. We analyzed the PCR products by automated capillary electrophoresis via an ABI 3730 DNA Analyzer (Applied Biosystems, Foster City, CA, USA) and performed genotyping with GeneMapper v4.0 software (Thermo Fisher Scientific Inc.).

\subsection{Productivity Measurement}

We examined specific leaf area (SLA, $\mathrm{cm}^{2} \mathrm{~g}^{-1}$; ratio between leaf area and dry leaf mass), a correlate of tree productivity $[46,65,66]$, of resprouting beaver-felled trees at Dry Beaver Creek in August 2010. This site was selected over the others because trees had similar canopy cover (0-5\%), their resprout growth was of similar age (estimated 2-3 years based upon bud scale scars) and height (mean $2.5 \mathrm{~m}$ ), and they occupied a small area within the river channel $(30 \times 70 \mathrm{~m})$, minimizing potentially confounding factors [67]. At Dry Beaver Creek, we also examined SLA of juvenile foliage of mature trees that were 
still standing at the time of leaf collection $(\mathrm{N}=4)$; although we had planned to sample all of the standing study trees, few were unfelled when we returned to the study site. SLA was not assessed at the other sites because of their heterogeneity in all of the above traits, each of which can dramatically drive variation, even among leaves of the same individual [67]. Twenty leaves were collected per tree, as recommended by Cornelissen et al. [46], and were standardized by the 5th plastocron position on each resprouting branch SLA was computed using WinFOLIA software for total leaf area measurements, followed by oven-drying $\left(60^{\circ} \mathrm{C}\right.$ for $\left.48 \mathrm{~h}\right)$ for each tree's total collected leaf weight.

\subsection{Statistical Approach}

We used GENHET [68], an R function that estimates 5 commonly used measures of individual multilocus heterozygosity. Because these metrics are highly correlated and provided similar results, here we report the proportion of heterozygous loci $(\mathrm{pHt})$ per individual tree, which was recommended by Chapman et al. [23]. Shannon's Diversity Index [69], arthropod richness, and arthropod abundance were used to quantify leaf arthropod communities. To examine the relationship between tree heterozygosity and the arthropod metrics, we employed multiple regression followed by simple linear regression after residual, and quantile plots indicated that the data were of constant variance and normally distributed. Analysis of covariance (ANCOVA) was used to determine whether the regression slopes of felled vs. unfelled trees differed significantly. To assess the association between tree productivity, individual multilocus heterozygosity, and arthropod community diversity, we regressed SLA on IMH and the above arthropod metrics. We performed partial correlation with SLA as the control variable to determine whether the relationship between IMH and arthropod community diversity was influenced by SLA. As a quality control exercise to assess whether some loci contributed to the results more than others, we examined the effect at each locus by classifying heterozygosity and performing student t-tests with Shannon's Diversity Index.

\subsection{Examination of Potentially Confounding Factors}

We assessed whether population substructure, underlying tree relatedness, or hybridization was present, which could bias our results. Two analytical approaches were employed to examine population substructure. First, we used a Bayesian clustering approach (STRUCTURE 2.3.3, [70-72]) to test whether the Verde River, Dry Beaver Creek, and Red Tank Draw sampling sites are more than one genetic population. Ten replicate runs were performed (admixture model, correlated allele frequencies) for 1-5 genetic clusters (K), for 50,000 burn-in, followed by 200,000 Markov chain Monte Carlo (MCMC) iterations. Second, we split tree IMH into categories, i.e., High, Intermediate, and Low, then ran Analysis of Molecular Variance (AMOVA) (program ARLEQUIN 3.5, [73]) with the three groups as subpopulations to arrive at $R_{S T}$ and its significance. To examine underlying patterns of relatedness in the aforementioned groups, we estimated the mean relatedness [74] of pairs of trees from genotypic data, then tested for among- and within-group differences. Although introgression from narrowleaf cottonwoods (Populus angustifolia, the most geographically proximate Populus spp.) to Fremont is not common [75,76], we nonetheless employed program STRUCTURE 2.3.3 to ascertain whether any trees were indeed hybrids, using the settings mentioned above. We tested our study population with two populations of narrowleaf: trees from the Blue River, Arizona, using 6 microsatellite loci in common ( $\mathrm{N}=17$; [77]), and trees from the San Miguel River, Colorado, using 8 loci in common $(\mathrm{N}=8$; F. Walker, unpublished data).

\section{Results}

\subsection{IMH Correlations for Felled Trees}

In agreement with our hypothesis that individual tree heterozygosity affects the arthropod community, we found that a felled tree's IMH was positively correlated with its arthropod community diversity (Shannon's Diversity Index; $R^{2}=0.56, p=0.005$; Figure 2a), 
species richness $\left(R^{2}=0.49, p=0.01\right.$; Figure $\left.2 b\right)$, and abundance $\left(R^{2}=0.36, p=0.04\right.$; Figure 2c).
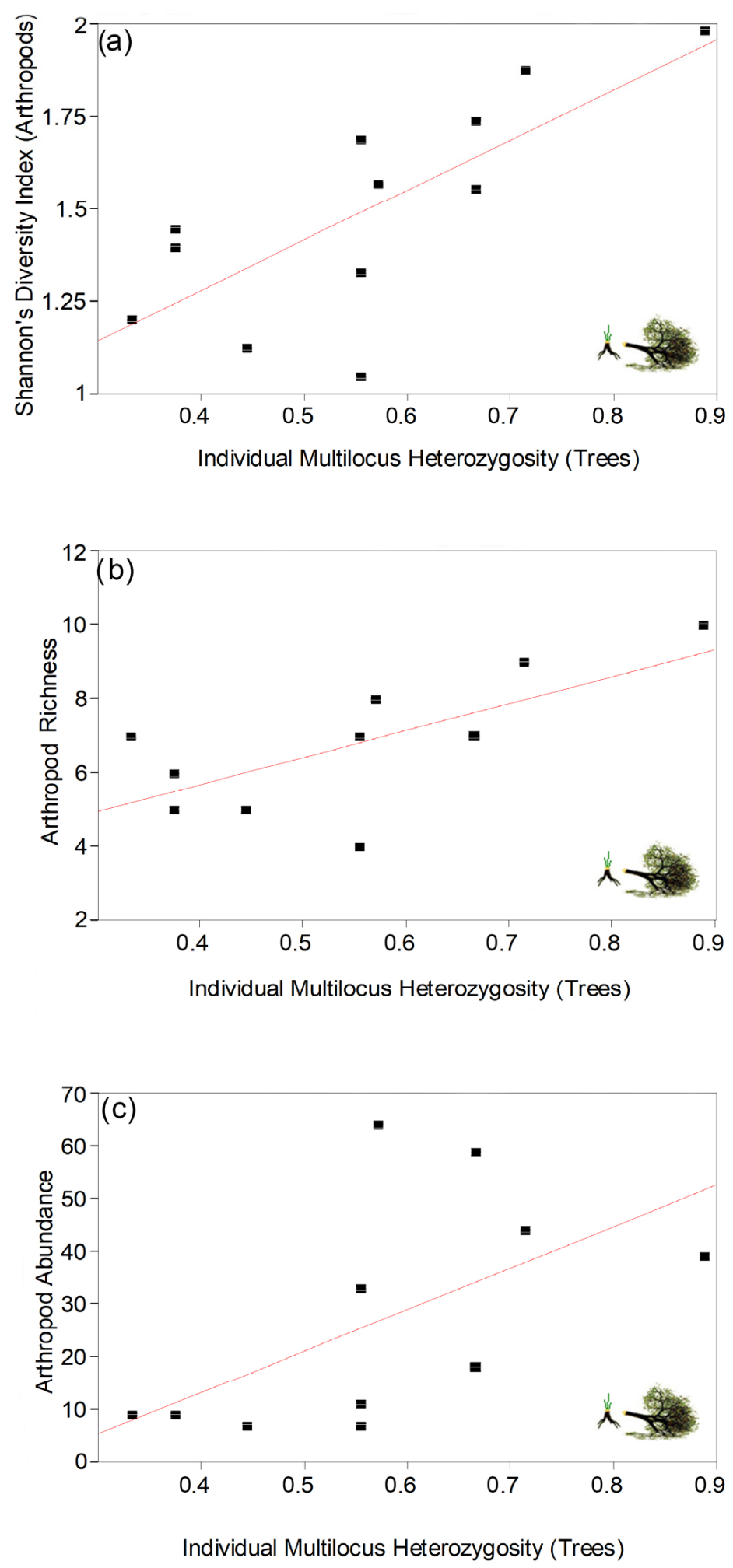

Figure 2. Individual multilocus heterozygosity of $P$. fremontii was strongly associated with leaf arthropod diversity: (a) Shannon's Diversity Index ( $\left.\mathrm{y}=0.737+1.358 \mathrm{x}, \mathrm{R}^{2}=0.56, p=0.005\right)$; (b) species richness $\left(\mathrm{y}=2.756+7.301 \mathrm{x}, \mathrm{R}^{2}=0.49, p=0.01\right) ;(\mathrm{c})$ arthropod abundance $\left(\mathrm{y}=2.756+7.301 \mathrm{x}, \mathrm{R}^{2}=0.36\right.$, $p=0.04)$. 
In examining potential hypotheses that could mechanistically account for the above $\mathrm{IMH} /$ arthropod community findings, we found support for the IMH/productivity hypothesis. At Dry Beaver Creek, where it was tractable to measure productivity, multiple regression analysis indicated that for beaver-felled trees, a tree's arthropod community diversity (Shannon's Diversity Index; response variable) could be predicted by its IMH and SLA (factor variables) $\left(\mathrm{R}^{2}=0.52\right.$; ANOVA for model: $\left.F(2,11)=4.28, p=0.05\right)$. A felled tree's IMH was positively correlated with its SLA (simple linear regression, $\mathrm{R}^{2}=0.45, p=0.02$; Figure 3a). Partial correlation revealed that the relationship between IMH and arthropod community diversity was dependent, in part, on SLA (correlation coefficient between IMH and Shannon's Diversity Index decreased from 0.72 to 0.57 when SLA was partialed out; $p=0.08)$.
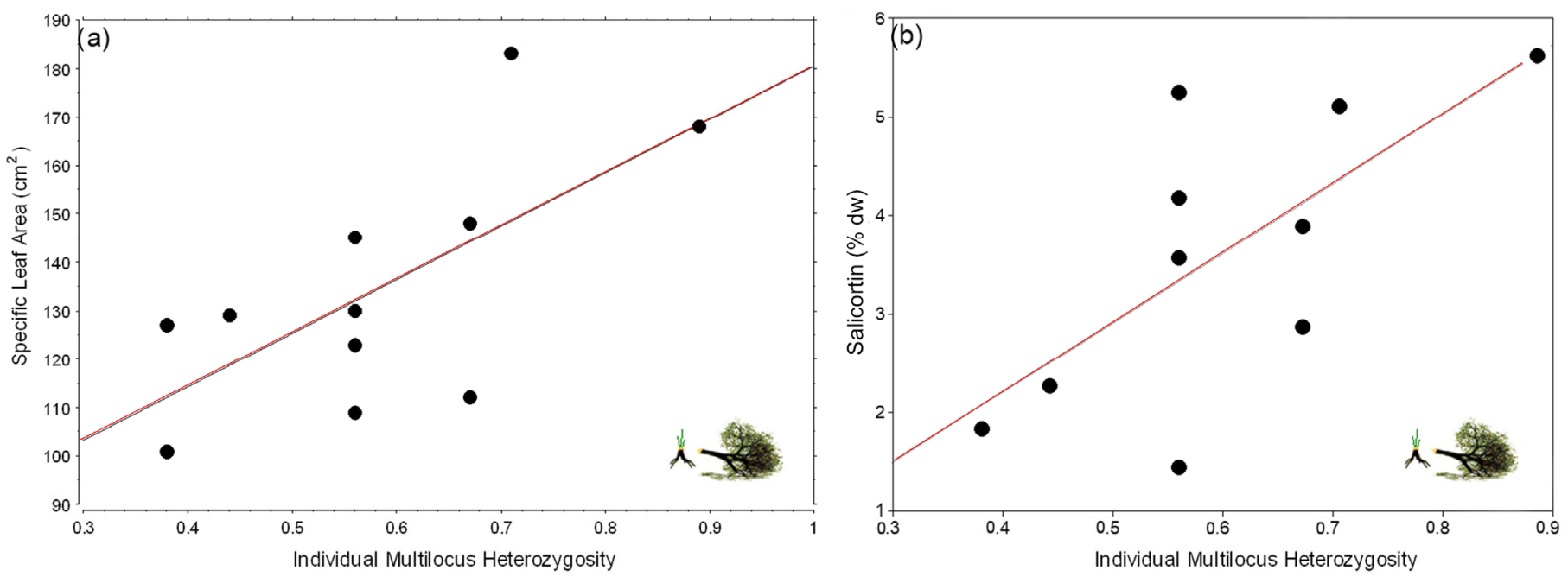

Figure 3. Individual multilocus heterozygosity of resprouting beaver-felled $P$. fremontii was associated with a leaf trait and twig chemistry. For P. fremontii at Arizona's Dry Beaver Creek, (a) specific leaf area, which is positively linked to productivity, increased with individual tree heterozygosity $\left(y=69.97+110.55 x, R^{2}=0.45, p=0.02\right) ;(b)$ salicortin concentration increased with individual tree heterozygosity $\left(\mathrm{y}=-0.62+7.06 \mathrm{x}, \mathrm{R}^{2}=0.47, p=0.03\right)$.

A felled tree's IMH was also positively correlated with twig salicortin concentration. This finding supports the hypothesis that beaver felling of trees induces phytochemical changes in resprout growth that may be important for deterring future browsing by beavers (i.e., the heterozygosity-phytochemistry hypothesis). Figure $3 \mathrm{~b}$ shows the relationship between IMH and salicortin level $(p=0.03)$. There was no relationship between IMH and nitrogen concentration $\left(R^{2}=0.28, p=0.12\right)$.

The other nearby drainages had similar relationships between individual multilocus heterozygosity and arthropod communities. We combined data from Verde and Red Tank Draw (due to their small sample sizes) and found a positive non-significant trend for Shannon's Diversity Index and IMH $\left(\mathrm{N}=12, \mathrm{R}^{2}=0.15, p=0.17\right)$, as well as for salicortin level and IMH $\left(\mathrm{N}=9, \mathrm{R}^{2}=0.34, p=0.10\right)$, in resprouting beaver-felled trees. For all sites combined, arthropod community diversity (Figure $4 ; R^{2}=0.33, p=0.004$ ), richness $\left(R^{2}=0.24, p=0.01\right)$, and abundance $\left(R^{2}=0.18, p=0.04\right)$ significantly increased with individual multilocus heterozygosity in resprouting beaver-felled trees $(\mathrm{N}=25)$. 


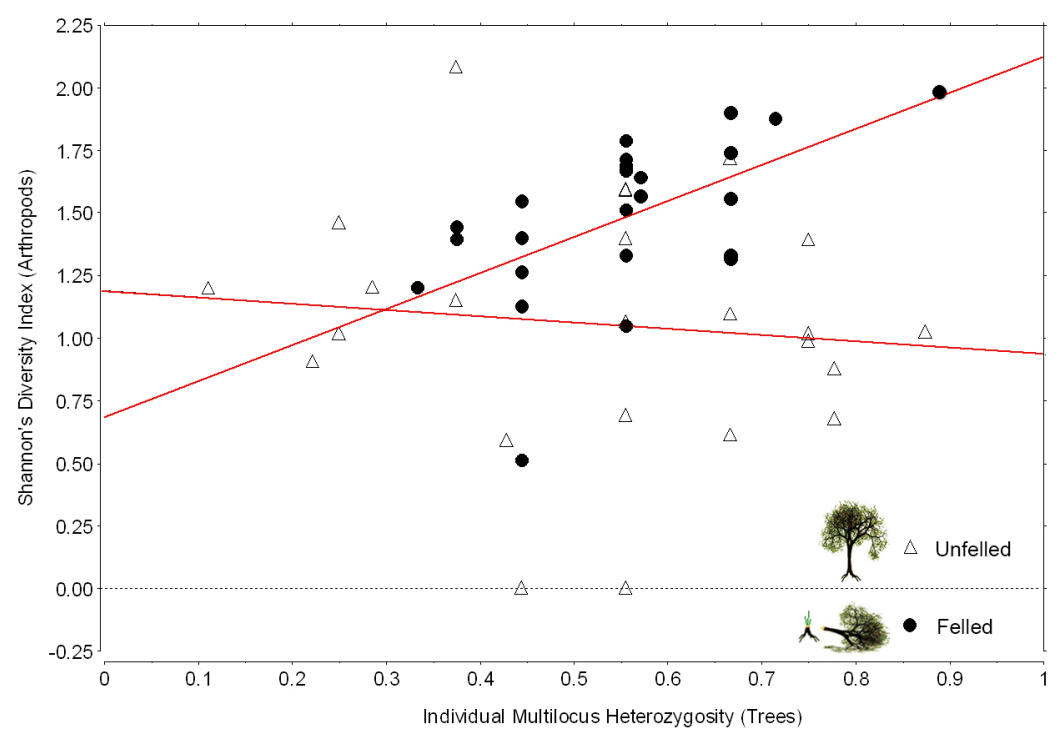

Figure 4. Individual multilocus heterozygosity of beaver-felled P. fremontii was associated with leaf arthropod community diversity at all sites. In Arizona's Verde River area, the relationship was significantly positive for resprouting beaver-felled trees, but not for trees that were unfelled (beaver-felled: $\mathrm{y}=0.69+1.44 \mathrm{x}, \mathrm{R}^{2}=0.33, p=0.004$; unfelled: $\left.\mathrm{y}=1.19-0.25 \mathrm{x}, \mathrm{R}^{2}=0.01, p=0.62\right)$. This difference between felled and unfelled trees was significant (ANCOVA interaction term: $F(1,48)=4.89$, $p=0.03)$.

\subsection{Contrasts of Felled and Unfelled Trees}

In agreement with our hypothesis that trees not felled by beavers would lack a link between heterozygosity and arthropods, we found no relationship between a tree's IMH and its arthropod community diversity (Figure $3, \mathrm{~N}=23 ; p=0.62, \mathrm{R}^{2}=0.01$ ), richness $\left(p=0.25, \mathbf{R}^{2}=0.06\right)$, or abundance $\left(p=0.42, \mathbf{R}^{2}=0.03\right)$. There was also no relationship between IMH and salicortin $\left(\mathrm{N}=25 ; p=0.15, \mathrm{R}^{2}=0.08\right)$ or IMH and specific leaf area $\left(\mathrm{N}=4 ; p=0.91, \mathrm{R}^{2}=0.009\right)$, although the sample size for the latter was small due to beavers subsequently felling trees.

These differences between felled and unfelled trees were significant for arthropod community diversity and richness, but not abundance (ANCOVA interaction terms for diversity: $F(1,48)=4.88, p=0.03$; richness: $F(1,48)=6.89, p=0.01$; abundance: $F(1,48)=1.86$, $p=0.18)$. These results indicate that beaver-felled trees had greater arthropod community diversity and richness than unfelled trees, which is explored in another paper [54].

\subsection{Alternative Hypotheses}

Differences between felled and unfelled trees were not due to confounding factors. There was no evidence of genetic substructuring between sites $(K=1$ resulted in the highest log-likelihood) or between trees with different levels of heterozygosity (AMOVA, $\left.\mathrm{R}_{\mathrm{ST}}=0.001, p=0.61\right)$. Mean pairwise relatedness between heterozygosity classes did not differ $(p=0.24)$, nor was there evidence of hybridization $(K=2$ resulted in the highest log-likelihoods for both datasets). Sites did not differ in tree heterozygosity (see below) or arthropod community diversity or richness ( $p=0.70$ and 0.40$)$; it was thus appropriate to pool site data.

\subsection{Locus Behavior}

The microsatellite loci employed in this study were highly discriminating with regard to individual tree identity: the probability of two randomly selected trees sharing a multilocus genotype was $1.66 \times 10^{-6}$, and the probability of full siblings doing so was 0.003 [78]. All loci conformed to Hardy-Weinberg expectations, and there was no evidence of linkage disequilibrium between locus pairs (program GENEPOP 4.0.10; [79]). The sig- 
nificant results for beaver-felled trees were not driven by a strong effect at particular loci. The per locus relationship between heterozygosity and arthropod community diversity was examined because it yielded the strongest overall result. Although one locus was significant $(p=0.03)$, it was an order of magnitude less than the multilocus result; five other loci, although not significant, followed in the same direction, and none was in the opposite direction.

\section{Discussion}

\subsection{The IMH-Arthropod Correlation as It Relates to Productivity and Plant Defense}

This work links genetic diversity (IMH) of the individual tree to community diversity. Arthropod diversity, as measured by Shannon's diversity index, and arthropod richness and abundance provided significant signals of the positive relationship with IMH, with the former being the strongest. In order to examine causality, the correlational patterns found in this study require experimental testing in a nearby common garden. A possible mechanism that may promote the arthropod-heterozygosity correlation that we examined is increased growth rate.

Since resprouting beaver-felled trees already have significant root systems, it is likely that they will allocate biomass to leaves, and thus any heterozygosity-driven differences in relative growth rate, such as SLA, will be readily apparent. A tradeoff often exists between root and leaf growth, with trees investing in one at the expense of the other [66]. In our study, higher SLA appeared to be attractive to arthropods. In many plant species, high SLA is correlated with high foliar nitrogen concentration, and both traits make leaves more attractive to herbivores $[44,80,81]$. Indeed, herbivores have been found to prefer high-SLA leaves in the field [44] and in the lab [67], and Martinsen et al. [59] found that beaver-felled $P$. angustifolia contained higher foliar nitrogen than unfelled control clones of the same genotypes. That the partial correlation results, showing a positive relationship between IMH and arthropod community diversity after accounting for joint covariance with SLA, approached significance $(p=0.08)$ may indicate that we have captured only one of multiple productivity measures that may be driving the relationship. We suggest that future studies include additional productivity estimates.

The significant correlation between IMH and salicortin may suggest that this phenolic glycoside increases following felling as a deterrent to further herbivory by beavers. It also suggests that heterozygosity facilitates this induction, although controlled experimental tests are required to draw this conclusion. Although no studies have examined beaver choice based on pre-felling salicortin levels, indirect evidence for the role of this phytochemical as a repellant was suggested by Durben et al. [54], who found higher concentrations of salicortin in resprout growth of beaver-felled $P$. fremontii than in juvenile growth of unfelled trees. Other mammalian herbivores avoid eating trembling aspen (Populus tremuloides) with leaves that have high concentrations of salicortin (North American porcupines, Erethizon dorsatum, [48]; elk, Cervus canadensis, [49]). Because we tested the phytochemistry of twigs that beavers feed upon and not of leaves (for which we quantified foliar arthropods), we do not infer responses of foliar arthropods to this IMH-salicortin relationship. However, Martinsen et al. [59] found that salicortin was the most abundant phenolic glycoside and that concentrations in the leaves were nearly two times greater in beaver-felled, resprouting trees (mostly complex backcross hybrids resembling $P$. angustifola with a few genotypes of $P$. fremontii and P. angustifolia) than in unfelled control trees of the same replicated genotypes. Similarly, they found that total nitrogen was nearly $20 \%$ greater in the leaves of resprout growth versus those of control trees. Further, Durben et al. [54] found these same salicortin and nitrogen relationships in the twigs of beaver-felled $P$. fremontii relative to those of unfelled trees. These findings suggest that twig and leaf salicortin could be positively correlated, although additional research is needed to confirm or reject this conclusion. We did not find a relationship between IMH and total nitrogen concentrations.

In plants, heterozygosity correlations have been found that can have clear relationships with productivity, fitness, environmental stress, and/or pathogens/herbivory. For example, 
the link between heterozygosity and fitness is believed to accrue with age in sexual tree species [82]; this may be the reason why long-lived species are most often observed to have an excess of heterozygotes [83]. For instance, in the American chestnut (Castanea dentata), heterozygotes had slightly higher growth rates, which over time produce a major excess of heterozygotes, and a clear heterozygote advantage as a consequence of the chestnut blight pandemic [43]. This pandemic has nearly eradicated sexual reproduction, allowing clonal heterozygous genotypes to dominate populations due to their growth advantage over the past 70 years. In aspen (Populus tremuloides), the growth rate increased with individual heterozygosity [42,83,84], and did so for males more than for females [41]. Cole et al. [39,41] found a tradeoff in which growth in aspens is positively related to heterozygosity and negatively related to condensed tannins. They suggested that episodes of pathogen or herbivore attacks alternated the selection for trees with high heterozygosity and high growth with that for trees with low heterozygosity and defensive tannin production. In mountain pine (Pinus uncinata Ram.), juveniles showed higher heterozygosity and growth rates, a relationship not seen for adult trees [85].

\subsection{Heterozygosity, Stress, and a Semi-Arid System}

In a variety of taxa, both microsatellites and allozymes show that the heterozygosityfitness correlations can be hidden in favorable conditions but become apparent when the organism experiences stress (eelgrass: [38]; common frog [86]; Perez's frog [87]). In pinyon pines (Pinus edulis), trees in high-stress abiotic environments (cinder fields) were more heterozygous than in reduced-stress environments (sandy-loam soils), and in the high-stress environment, trees genetically resistant to insect attack were more heterozygous than trees susceptible to insect attack [88]. Thus, it appears that abiotic and biotic stressors can reveal fitness-associated traits that also correlate with increased heterozygosity. Further, plant stress associated with climate change and reduced productivity has been demonstrated to have dramatic negative effects on a diverse arthropod community associated with pinyon pine in the Southwest. Stone et al. [89,90] found that for both juvenile and mature trees, arthropod richness and abundance on individual pinyon pine were positively correlated with the tree's radial trunk growth and that highly stressed trees with low productivity supported a very depauperate community relative to vigorously growing trees. This relationship was found to occur among trees within a stand, as well as across stands [91], and these community findings are in general agreement with the vigor hypothesis [92], according to which most herbivores prefer vigorously growing plants to feed upon because of their increased nutritional content. The present study extends this relationship to the underlying genetics (IMH) of individual plants.

In aspen, the effect of individual multilocus heterozygosity, as assessed by microsatellite markers, on growth rate was a simple linear relationship [42]. Because the association between heterozygosity and growth rate was additionally found in aspen studies employing isozymes [83,84], Cole et al. [42] postulated that both marker types yielded a signal of genome-wide inbreeding, in line with the general effects hypothesis for heterozygosityfitness correlations [93]. As with aspen, Fremont cottonwoods are dioecious obligate outcrossers. Despite this, some trees would be expected to express effects of inbreeding if sufficiently localized pollen and seed dispersal caused breeding between relatives (biparental inbreeding). This scenario is particularly plausible in riparian systems of the desert Southwest, such as intermittently flowing tributaries of the Verde River like Dry Beaver Creek, where relatively few trees inhabit a riparian corridor surrounded by expansive desert and where we found the strongest pattern. We propose that in this cottonwood system, the heterozygosity-productivity relationship may be a surrogate for a heterozygosity-fitness correlation and that this correlation is a consequence of variation in inbreeding, in accordance with the general effects hypothesis for heterozygosity-fitness correlations. Although inbreeding depression has been found to result in post-dispersal selection against inbred progeny and a corresponding increase in heterozygosity from juvenile to mature forest trees (e.g., [94]), in this study system it appears that mature trees 
with some degree of inbreeding were present. The new generation of juvenile growth following the new biotic stress of felling by beavers provides another opportunity for selection against inbred individuals.

\section{Conclusions}

In agreement with our hypothesis that interactions among foundation species have community-level effects, we found that genetic diversity (IMH) of individual resprouting beaver-felled trees was positively correlated with productivity, a phenolic glycoside (salicortin), and arthropod community richness, diversity, and abundance, whereas these correlations were absent for trees not felled by beavers. Thus, it appears that the tree heterozygosity/arthropod community/productivity/salicortin relationship only reveals itself in the presence of beavers that severely stress trees by removing nearly all of their aboveground biomass so that trees often die. This work provides a quartet of implications for heterozygosity-productivity (fitness) studies and conservation. First, IMH-fitness investigations should compare groups of organisms associated with populations experiencing different degrees of abiotic and biotic stress. Second, genetic diversity at the individual level can scale up to effect communities. Third, this effect is likely to be strongest where two or more foundation species interact, as with cottonwoods and beavers. Fourth, where conservation biologists have a choice of which source populations and individual genotypes to use in restoration, our results suggest that genetic diversity within individuals can positively affect biodiversity. Because these relationships are a product of biotic stress that occurred during a 19-year period of record drought years in the American Southwest that are projected to continue, it seems critical to be cognizant of how plant genetics including heterozygosity may interact with multiple stressors to affect plant survival and the communities they support.

Author Contributions: Conceptualization, F.M.W., T.G.W., S.M.S., R.D.; Methodology, F.M.W., R.D.; Formal Analysis, F.M.W.; Investigation, F.M.W., R.D.; Data Curation, F.M.W., R.D.; Writing-Original Draft Preparation, F.M.W.; Writing—Review \& Editing, F.M.W., T.G.W., S.M.S., R.L.L., R.D.; Visualization, F.M.W.; Supervision, S.M.S., T.G.W.; Project Administration, F.M.W.; Funding Acquisition, T.G.W., S.M.S., R.L.L. All authors have read and agreed to the published version of the manuscript.

Funding: This research was supported by NSF FIBR grant DEB-0425908, Macrosystems grants DEB-1340852 and 2017877, and BEE grant DEB-1914433.

Institutional Review Board Statement: Not applicable.

Informed Consent Statement: Not applicable.

Data Availability Statement: The data presented in this study are openly available in FigShare at https:// doi.org/10.6084/m9.figshare.14213486.v1.

Acknowledgments: We thank the U.S. Forest Service for permission to work at our study sites, R. Paulk, C. Ridenour, and W. White for assistance with arthropod surveys, N. Rubert-Nason for assistance with phytochemistry, Northern Arizona University's Cottonwood Ecology Group for valuable input, and the American beaver for bringing it home.

Conflicts of Interest: The authors declare no conflict of interest.

\section{References}

1. Whitham, T.G.; Bailey, J.K.; Schweitzer, J.A.; Shuster, S.M.; Bangert, R.K.; Leroy, C.J.; Lonsdorf, E.V.; Allan, G.J.; DiFazio, S.P.; Potts, B.M.; et al. A framework for community and ecosystem genetics: From genes to ecosystems. Nat. Rev. Genet. 2006, 7, 510-523. [CrossRef] [PubMed]

2. Hughes, A.R.; Inouye, B.D.; Johnson, M.T.J.; Underwood, N.; Vellend, M. Ecological consequences of genetic diversity. Ecol. Lett. 2008, 11, 609-623. [CrossRef] [PubMed]

3. Johnson, M.T.; Stinchcombe, J.R. An emerging synthesis between community ecology and evolutionary biology. Trends Ecol. Evol. 2007, 22, 250-257. [CrossRef]

4. Whitham, T.G.; Gehring, C.A.; Lamit, L.J.; Wojtowicz, T.; Evans, L.M.; Keith, A.R.; Smith, D.S. Community specificity: Life and afterlife effects of genes. Trends Plant Sci. 2012, 17, 271-281. [CrossRef] [PubMed] 
5. Whitham, T.G.; Allan, G.J.; Cooper, H.F.; Shuster, S.M. Intraspecific Genetic Variation and Species Interactions Contribute to Community Evolution. Annu. Rev. Ecol. Evol. Syst. 2020, 51, 587-612. [CrossRef]

6. Crutsinger, G.M. A community genetics perspective: Opportunities for the coming decade. New Phytol. 2016, 210, 65-70. [CrossRef] [PubMed]

7. Roches, S.D.; Post, D.M.; Turley, N.E.; Bailey, J.K.; Hendry, A.P.; Kinnison, M.T.; Schweitzer, J.A.; Palkovacs, E.P. The ecological importance of intraspecific variation. Nat. Ecol. Evol. 2018, 2, 57-64. [CrossRef]

8. Wade, M.J. The co-evolutionary genetics of ecological communities. Nat. Rev. Genet. 2007, 8, 185-195. [CrossRef]

9. Reynolds, L.K.; McGlathery, K.J.; Waycott, M. Genetic Diversity Enhances Restoration Success by Augmenting Ecosystem Services. PLOS ONE 2012, 7. [CrossRef]

10. Bangert, R.K.; Turek, R.J.; Rehill, B.; Wimp, G.M.; Schweitzer, J.A.; Allan, G.J.; Bailey, J.K.; Martinsen, G.D.; Keim, P.; Lindroth, R.L.; et al. A genetic similarity rule determines arthropod community structure. Mol. Ecol. 2005, 15, 1379-1391. [CrossRef] [PubMed]

11. Wimp, G.M.; Young, W.P.; Woolbright, S.A.; Martinsen, G.D.; Keim, P.; Whitham, T.G. Conserving plant genetic diver-sity for dependent animal communities. Ecol. Lett. 2004, 7, 776-780. [CrossRef]

12. Crutsinger, G.M.; Reynolds, W.N.; Classen, A.T.; Sanders, N.J. Disparate effects of plant genotypic diversity on foliage and litter arthropod communities. Oecologia 2008, 158, 65-75. [CrossRef]

13. Ferrier, S.M.; Bangert, R.K.; Hersch-Green, E.I.; Bailey, J.K.; Allan, G.J.; Whitham, T.G. Unique arthropod communities on different host-plant genotypes results in greater arthropod diversity. Arthropod-Plant Interact. 2012, 6, 187-195. [CrossRef]

14. Castagneyrol, B.; Lagache, L.; Giffard, B.; Kremer, E.; Jactel, H. Genetic Diversity Increases Insect Herbivory on Oak Sap-lings. PLOS ONE 2012, 7. [CrossRef]

15. Evans, L.M.; Kaluthota, S.; Pearce, D.W.; Allan, G.J.; Floate, K.; Rood, S.; Whitham, T.G. Bud phenology and growth are subject to divergent selection across a latitudinal gradient in Populus angustifolia and impact adaptation across the distributional range and associated arthropods. Ecol. Evol. 2016, 6, 4565-4581. [CrossRef] [PubMed]

16. Keith, A.R.; Bailey, J.K.; Lau, M.K.; Whitham, T.G. Genetics-based interactions of foundation species affect community diversity, stability and network structure. Proc. R. Soc. B Boil. Sci. 2017, 284. [CrossRef] [PubMed]

17. Holeski, L.M.; Hillstrom, M.L.; Whitham, T.G.; Lindroth, R.L. Relative importance of genetic, ontogenetic, induction, and seasonal variation in producing a multivariate defense phenotype in a foundation tree species. Oecologia 2012, 170, 695-707. [CrossRef]

18. Lamit, L.J.; Busby, P.E.; Lau, M.K.; Compson, Z.G.; Wojtowicz, T.; Keith, A.R.; Zinkgraf, M.S.; Schweitzer, J.A.; Shuster, S.M.; Gehring, C.A.; et al. Tree genotype mediates covariance among communities from microbes to lichens and arthropods. J. Ecol. 2015, 103, 840-850. [CrossRef]

19. Barbour, R.C.; Forster, L.G.; Baker, S.C.; Steane, D.A.; Potts, B.M. Biodiversity Consequences of Genetic Variation in Bark Characteristics within a Foundation Tree Species. Conserv. Biol. 2009, 23, 1146-1155. [CrossRef] [PubMed]

20. Barbour, R.C.; O’Reilly-Wapstra, J.M.; De Little, D.W.; Jordan, G.J.; Steane, R.A.; Humphreys, J.R.; Bailey, J.K.; Whitham, T.G.; Potts, B.M. A geographic mosaic of genetic variation within a foundation tree species and its community-level consequences. Ecology 2009, 90, 1762-1772. [CrossRef]

21. Barker, H.L.; Holeski, L.M.; Lindroth, R.L. Genotypic variation in plant traits shapes herbivorous insect and ant communities on a foundation tree species. PLoS ONE 2018, 13. [CrossRef]

22. Szulkin, M.; Bierne, N.; David, P. Heterozygosity-Fitness Correlations: A Time for Reappraisal. Evology 2010, 64, 1202-1217. [CrossRef] [PubMed]

23. Hapman, J.R.C.; Nakagawa, S.; Oltman, D.W.C.; Slate, J.; Heldon, B.C.S. A quantitative review of heterozygosity-fitness correlations in animal populations. Mol. Ecol. 2009, 18, 2746-2765. [CrossRef] [PubMed]

24. Hansson, B.; Westerberg, L. On the correlation between heterozygosity and fitness in natural populations. Mol. Ecol. 2002, 11, 2467-2474. [CrossRef]

25. Coltman, D.W.; Slate, J. Microsatellite measures of inbreeding: A meta-analysis. Evolution 2003, 57, 971-983. [CrossRef]

26. Ohta, T.; Cockerham, C.C. Detrimental genes with partial selfing and effects on a neutral locus. Genet. Res. 1974, 23, 191-200. [CrossRef] [PubMed]

27. Ohta, T. Associative overdominance caused by linked detrimental mutations. Genet. Res. 1971, 18, 277-286. [CrossRef]

28. Slate, J.; Pemberton, J.M. Admixture and patterns of linkage disequilibrium in a free-living vertebrate population. J. Evol. Biol. 2007, 20, 1415-1427. [CrossRef]

29. Charlesworth, D.; Charlesworth, B. Inbreeding depression and its evolutionary consequences. Ann. Rev. Ecol. Syst. 1987, 18, 237-268. [CrossRef]

30. Pérez-González, J.; Carranza, J.; Torres-Porras, J.; Fernández-García, J.L. Low Heterozygosity at Microsatellite Markers in Iberian Red Deer with Small Antlers. J. Hered. 2010, 101, 553-561. [CrossRef]

31. Acevedo-Whitehouse, K.; Petetti, L.; Duignan, P.; Castinel, A. Hookworm infection, anaemia and genetic variability of the New Zealand sea lion. Proc. R. Soc. B Boil. Sci. 2009, 276, 3523-3529. [CrossRef] [PubMed]

32. Coltman, D.W.; Pilkington, J.G.; Smith, J.A.; Pemberton, J.M. Parasite-Mediated Selection against Inbred Soay Sheep in a Free-Living, Island Population. Evolution 1999, 53, 1259. [CrossRef] [PubMed]

33. Gompper, M.E.; Monello, R.J.; Eggert, L.S. Genetic variability and viral seroconversion in an outcrossing vertebrate population. Proc. R. Soc. B Boil. Sci. 2010, 278, 204-210. [CrossRef] [PubMed] 
34. Cohas, A.; Bonenfant, C.; Kempenaers, B.; Allainé, D. Age-specific effect of heterozygosity on survival in alpine mar-mots, Marmota marmota. Mol. Ecol. 2009, 18, 1491-1503. [CrossRef] [PubMed]

35. Da Silva, A.; Gaillard, J.-M.; Yoccoz, N.G.; Hewison, A.J.M.; Galan, M.; Coulson, T.; Allainé, D.; Vial, L.; Delorme, D.; Van Laere, G.; et al. Heterozygisity-fitness correlations revealed by neutral and candidate gene markers in roe deer from a long-term study. Evolution 2009, 63, 403-417. [CrossRef]

36. Küpper, C.; Kosztolányi, A.; Augustin, J.; Dawson, D.; Burke, T.; Székely, T. Heterozygosity-fitness correlations of con-served microsatellite markers in Kentish plovers Charadrius alexandrinus. Mol. Ecol. 2010, 19, 5172-5185. [CrossRef]

37. Selonen, V.; Hanski, I.K. Condition-dependent, phenotype-dependent and genetic dependent factors in the natal disper-sal of a solitary rodent. J. Anim. Ecol. 2010, 79, 1093-1100. [CrossRef]

38. Williams, S.L. Reduced genetic diversity in eelgrass transplantations affects both population growth and individual fit-ness. Ecol. Appl. 2001, 11, 1472-1488. [CrossRef]

39. Cole, C.T.; Morrow, C.J.; Barker, H.L.; Rubert-Nason, K.F.; Riehl, J.F.L.; Köllner, T.G.; Lackus, N.D.; Lindroth, R.L. Growing up aspen: Ontogeny and trade-offs shape growth, defence and reproduction in a foundation species. Ann. Bot. 2021, 127, 505-517. [CrossRef]

40. Hammerli, A.; Reusch, T.B.H. Inbreeding depression influences genet size distribution in a marine angiosperm. Mol. Ecol. 2003, 12, 619-629. [CrossRef]

41. Cole, C.T.; Stevens, M.T.; Anderson, J.E.; Lindroth, R.L. Heterozygosity, gender, and the growth-defense trade-off in quaking aspen. Oecologia 2016, 181, 381-390. [CrossRef]

42. Cole, C.T.; Anderson, J.E.; Lindroth, R.L.; Waller, D.M. Rising concentrations of atmospheric $\mathrm{CO}_{2}$ have increased growth in natural stands of quaking aspen (Populus tremuloides). Glob. Chang. Biol. 2009, 16, 2186-2197. [CrossRef]

43. Stilwell, K.L.; Wilbur, H.M.; Werth, C.R.; Taylor, D.R. Heterozygote advantage in the American chestnut, Castanea dentata (Fagaceae). Am. J. Bot. 2003, 90, 207-213. [CrossRef]

44. Pérez-Harguindeguy, N.; Díaz, S.; Vendramini, F.; Cornelissen, J.H.C.; Gurvich, D.E.; Cabido, M. Leaf Traits and herbi-vore selection in the field and cafeteria experiments. Austral Ecol. 2003, 28, 642-650. [CrossRef]

45. Wright, I.J.; Cooke, J.; Cernusak, L.A.; Hutley, L.B.; Scalon, M.; Tozer, W.C.; Lehmann, C. Stem diameter growth rates in a fire-prone savanna correlate with photosynthetic rate and branch-scale biomass allocation, but not specific leaf area. Austral Ecol. 2019, 44, 339-350. [CrossRef]

46. Cornelissen, J.H.C.; Lavorel, S.; Garnier, E.; Díaz, S.; Buchmann, N.; Gurvich, D.E.; Reich, P.B.; ter Steege, H.; Morgan, H.D.; van der Heijden, M.G.A.; et al. A handbook of protocols for standardized and easy measurement of plant func-tional traits worldwide. Am. J. Bot. 2003, 51, 335-380. [CrossRef]

47. Patyk, K.; Turmelle, A.; Blanton, J.D.; Rupprecht, C.E. Trends in National Surveillance Data for Bat Rabies in the United States: 2001-2009. Vector-Borne Zoonotic Dis. 2012, 12, 666-673. [CrossRef]

48. Diner, B.; Berteaux, M.; Fyles, J.; Lindroth, R.L. Behavioral archives link the chemistry and clonal structure of trembling aspen to the food choice of North American porcupine. Oecologia 2009, 160, 687-695. [CrossRef]

49. Stuart, C.W.; Scott, W.; Jason, V.; Richard, L.L. Aspen Decline, Aspen Chemistry, and Elk Herbivory: Are They Linked? Rangelands 2008, 30, 17-21. [CrossRef]

50. Axelsson, E.P.; Senior, J.K. The extended consequences of genetic conductivity: Mating distance affects community phe-notypes in Norway spruce. Ecol. Evol. 2018, 8, 11645-11655. [CrossRef]

51. Campbell, S.A.; Thaler, J.S.; Kessler, A. Plant chemistry underlies herbivore-mediated inbreeding depression in nature. Ecol. Lett. 2013, 16, 252-260. [CrossRef]

52. Schrieber, K.; Schweiger, R.; Kroner, L.; Muller, C. Inbreeding diminishes herbivore-induced metabolic responses in na-tive and invasive plant populations. J. Ecol. 2019, 107, 923-936. [CrossRef]

53. Williams, A.P.; Cook, E.R.; Smerdon, J.E.; Cook, B.I.; Abatzoglou, J.T.; Bolles, K.; Baek, S.H.; Badger, A.M.; Livneh, B. Large contribution from anthropogenic warming to an emerging North American megadrought. Science 2020, 368, 314-318. [CrossRef] [PubMed]

54. Durben, R.M.; Walker, F.M.; Holeski, L.; Keith, A.; Kovacs, Z.; Hurteau, S.R.; Lindroth, R.L.S.; Shuster, S.M.; Whitham, T.G. Beavers, bugs and chemistry: A mammalian herbivore changes chemistry composition and arthropod communities in foundation tree species. Forests 2021.

55. Bailey, J.K.; Schweitzer, J.A.; Rehill, B.J.; Lindroth, R.L.; Martinsen, G.D.; Whitham, T.G. Beavers as Molecular Geneticists: A Genetic Basis to the Foraging of An Ecosystem Engineer. Ecology 2004, 85, 603-608. [CrossRef]

56. Waltz, A.M.; Whitham, T.G. Plant development affects arthropod communities: Opposing impacts of species removal. Ecology 1997, 78, 2133-2144. [CrossRef]

57. Wimp, G.M.; Martinsen, G.D.; Floate, K.D.; Bangert, R.K.; Whitham, T.G. Plant genetic determinants of arthropod com-munity structure and diversity. Evolution 2005, 59, 61-69. [CrossRef] [PubMed]

58. Wimp, G.M.; Wooley, S.; Bangert, R.K.; Young, W.P.; Martinsen, G.D.; Keim, P.; Rehill, B.; Lindroth, R.L.; Whitham, T.G. Plant genetics predicts intra-annual variation in phytochemistry and arthropod community structure. Mol. Ecol. 2007, 16, 5057-5069. [CrossRef] [PubMed]

59. Martinsen, G.D.; Driebe, E.M.; Whitham, T.G. Indirect interactions mediated by changing plant chemistry: Beaver browsing benefits beetles. Ecology 1998, 79, 192-200. [CrossRef] 
60. Lindroth, R.; Kinney, K.K.; Platz, C.L. Responses of Diciduous Trees to Elevated Atmospheric $\mathrm{CO}_{2}$ : Productivity, Phytochemistry, and Insect Performance. Ecology 1993, 74, 763-777. [CrossRef]

61. Parsons, W.F.J; Bockheim, J.G.; Lindroth, R.L. Independent, Interactive, and Species-Specific Responses of Leaf Litter Decomposition to Elevated CO2 and O3 in a Northern Hardwood Forest. Ecosystems 2008, 11, 505-519. [CrossRef]

62. Liston, A.; Rieseberg, L.H.; Adams, R.P.; Do, N.; Ge-Lin, Z. A Method for Collecting Dried Plant Specimens for DNA and Isozyme Analyses, and the Results of a Field Test in Xinjiang, China. Ann. Mo. Bot. Gard. 1990, 77, 859-863. [CrossRef]

63. Woolbright, S.A.; DiFazio, S.P.; Yin, T.; Martinsen, G.D.; Zhang, X.; Allan, G.J.; Whitham, T.G.; Keim, P. A dense linkage map of hybrid cottonwood (Populus fremontii_P. angustifolia) contributes to long-term ecological research and compari-son mapping in a model forest tree. Heredity 2008, 100, 59-70. [CrossRef]

64. Tuskan, G.A.; DiFazio, S.; Jansson, S.; Bohlmann, J.; Grigoriev, I.; Hellsten, U.; Putnam, N.; Ralph, S.; Rombauts, S.; Salamov, A.; et al. The Genome of Black Cottonwood, Populus trichocarpa (Torr. \& Gray). Science 2006, 313, 1596-1604. [CrossRef] [PubMed]

65. Dunlap, J.M.; Stettler, R.F. Genetic variation and productivity of Populus trichocarpa and its hybrids. X. Trait correlations in young black cottonwood from four river valleys in Washington. Trees 1998, 13, 28-39. [CrossRef]

66. Imada, S.; Yamanaka, N.; Tamai, S. Contribution of root growth responses to leaf traits and relative growth rate of Pop-ulus alba under different water-table conditions. Trees 2010, 24, 1163-1172. [CrossRef]

67. Poorter, H.; Niinemets, Ü.; Poorter, L.; Wright, I.J.; Villar, R. Causes and consequences of variation in leaf mass per area (LMA): A meta-analysis. New Phytol. 2009, 182, 565-588. [CrossRef]

68. Coulon, A. GENHET: An easy-to-use R function to estimate individual heterozygosity. Mol. Ecol. Resour. 2010, 10, 167-169. [CrossRef]

69. Magurran, A.E. Ecological Diversity and Its Measurement; Princeton University Press: Princeton, NJ, USA, 1988.

70. Evanno, G.; Regnaut, S.; Goudet, J. Detecting the number of clusters of individuals using the software structure: A simulation study. Mol. Ecol. 2005, 14, 2611-2620. [CrossRef]

71. Pritchard, J.K.; Stephens, M.; Donnelly, P. Inference of Population Structure Using Multilocus Genotype Data. Genetics 2000, 155, 945-959. [CrossRef]

72. Pritchard, J.K.; Wen, W. Documentation for Structure Software, Version 2; Department of Human Genetics, University of Chicago: Chicago, IL, USA, 2003.

73. Excoffier, L.; Lischer, H.E.L. Arlequin suite ver 3.5: A new series of programs to perform population genetics analyses under Linux and Windows. Mol. Ecol. Resour. 2010, 10, 564-567. [CrossRef]

74. Queller, D.C.; Goodnight, K.F. Estimating relatedness using genetic markers. Evolution 1989, 43, 258-275. [CrossRef]

75. Keim, P.; Paige, K.N.; Whitham, T.G.; Lark, K.G. Genetic analysis of an interspecific hybrid swarm of Populus: Occurrence of unidirectional introgression. Genetics 1989, 123, 557-565. [CrossRef] [PubMed]

76. Martinsen, G.D.; Whitham, T.G.; Turek, R.J.; Keim, P. Hybrid populations selectively filter gene introgression between species. Evolution 2001, 55, 1325-1335. [CrossRef] [PubMed]

77. Bothwell, H.M.; Cushman, S.A.; Woolbright, S.A.; Hersch-Green, E.I.; Evans, L.M.; Whitham, T.G.; Allan, G.J. Conserving threatened riparian ecosystems in the American West: Precipitation gradients and river networks drive genetic connectivity and diversity in a foundation riparian tree (Populus angustifolia). Mol. Ecol. 2017, 26, 5114-5132. [CrossRef]

78. Waits, L.; Luikart, G.; Taberlet, P. Estimating the probability of identity among genotypes in natural populations: Cau-tions and guidelines. Mol. Ecol. 2001, 10, 249-256. [CrossRef]

79. Raymond, M.; Rousset, F. GENEPOP (Version 1.2): Population Genetics Software for Exact Tests and Ecumenicism. J. Hered. 1995, 86, 248-249. [CrossRef]

80. Louault, F.; Pillar, V.D.; Aufrère, J.; Garnier, E.; Soussana, J.F. Plant traits and functional types in response to reduced disturbance in a semi-natural grassland. J. Veg. Sci. 2005, 16, 151-160. [CrossRef]

81. Wright, I.J.; Reich, P.B.; Westoby, M.; Ackerly, D.; Baruch, Z.; Bongers, F.; Cavender-Bares, J.; Chapin, T.; Cornelissen, J.H.C.; Diemer, M.; et al. The worldwide leaf economics spectrum. Nature 2004, 428, 821-827. [CrossRef] [PubMed]

82. Bush, R.M.; Smouse, P.E. Evidence for the adaptives ignificance of allozymes in forest trees. New For. 1992, 6, 179-196. [CrossRef]

83. Mitton, J.B.; Grant, M.C. Observations on the ecology and evolution of quaking aspen, Populus tremuloides, in the Colo-rado front range. Am. J. Bot. 1980, 67, 202-209. [CrossRef]

84. Jelinski, D.E. Associations between environmental heterogeneity, heterozygosity, and growth rates of Populus tremuloides in a cordilleran landscape. Arct. Alp. Res. 1993, 25, 183-188. [CrossRef]

85. González-Díaz, P.; Gazol, A.; Valbuena-Carabaña, M.; Sangüesa-Barreda, G.; Moreno-Urbano, A.; Zavala, M.A.; Camarero, J.J. Remaking a stand: Links between genetic diversity and tree growth in expanding Mountain pine populations. For. Ecol. Manag. 2020, 472. [CrossRef]

86. Lesbarréres, D.; Primmer, C.R.; Laurila, A.; Merilä, J. Environmental and population dependency of genetic variabil-ity-fitness correlations in Rana temporaria. Mol. Ecol. 2005, 14, 311-323. [CrossRef]

87. Schmeller, D.S.; Schregel, J.; Veith, M. The importance of heterozygosity in a frog's life. Naturwissenschaften 2007, 94, 360-366. [CrossRef]

88. Mopper, S.; Mitton, J.B.; Whitham, T.G.; Cobb, N.S.; Christensen, K.M. Genetic Differentiation and Heterozygosity in Pinyon Pine Associated with Resistance to Herbivory and Environmental Stress. Evology 1991, 45, 989-999. [CrossRef] [PubMed] 
89. Stone, A.C.; Gehring, C.A.; Whitham, T.G. Drought negatively affects communities on a foundation tree: Growth rings predict diversity. Oecologia 2010, 164, 751-761. [CrossRef] [PubMed]

90. Stone, A.C.; Gehring, C.A.; Cobb, N.S.; Whitham, T.G. Genetic-Based Susceptibility of a Foundation Tree to Herbivory Interacts With Climate to Influence Arthropod Community Composition, Diversity, and Resilience. Front. Plant Sci. $2018,9,1831$. [CrossRef] [PubMed]

91. Trotter, R.T.; Cobb, N.S.; Whitham, T.G. Arthropod community diversity and trophic structure: A comparison between extremes of drought-stress. Ecol. Entomol. 2008, 33, 1-11. [CrossRef]

92. Price, P.W. The Plant Vigor Hypothesis and Herbivore Attack. Oikos 1991, 62, 244. [CrossRef]

93. David, P. Heterozygosity-fitness correlations: New perspective on old problems. Heredity 1998, 80, 531-537. [CrossRef] [PubMed]

94. Nickolas, H.; Harrison, P.A.; Tilyard, P.; Vaillancourt, R.E.; Potts, B.M. Inbreeding depression and differential maladap-tation shape the fitness trajectory of two co-occurring Eucalyptus species. Ann. For. Sci. 2019, 76, 10-23. [CrossRef] 